\title{
MIR127 Pre-miRNA
}

National Cancer Institute

\section{Source}

National Cancer Institute. MIR127 Pre-miRNA. NCI Thesaurus. Code C82760.

MIR127pre-miRNA is an oligoribonucleotide that is encoded by the MIR127 gene and is involved in the regulation of gene expression. 